\title{
KAJIAN GAMIFIKASI MEKANIK SEBAGAI VARIABEL DALAM LITERASI MEDIA BOARD GAME
}

\author{
Fadhilah Amalia ${ }^{1}$ \\ Alvanov Zpalanzani Mansoor ${ }^{2}$
}

Diterima Mei. o3, 2021; Disetujui Juni. o3, 2021.

\begin{abstract}
Abstrak: Seiring dengan perubahan yang terjadi di masyarakat abad 21, dunia disuguhi oleh perubahan industri media yang begitu pesat seiring dengan kemajuan teknologi yang ada. Ragam media yang terus muncul dan berkembang di seluruh lapisan masyarakat memberikan dampak yang signifikan, salah satunya adalah media board game. Berbeda dengan digital media, board game melibatkan benda fisik/prototype dan atmosfir sosial yang sulit untuk direplikasi dalam digital media. Fenomena tersebut menjadi perhatian peneliti untuk meneliti kemampuan literasi media remaja, khususnya terhadap media board game sebagai sebuah media edukasi. Literasi media adalah kemampuan untuk mencari, menemukan, dan menggunakan informasi dari pesan media dengan cara mengadaptasi kemampuan kognitif dan berpikir kritis dalam menganalisa dan mempertanyakan pesan media yang dilihat, dibaca, dan ditonton. Literasi memiliki cangkupan yang luas dan dipercaya sebagai benteng bagi khalayak agar mampu berpikir kritis. Penelitian ini dilakukan untuk mengkaji elemen gamifikasi mekanik sebagai variabel independen literasi media pada model pembelajaran board game, berfokus pada konsep literasi media berbasis kompetensi individual (individual competence) utamanya pada kriteria critical understanding.
\end{abstract}

Kata Kunci: board game; critical understanding; elemen gamifikasi; literasi media

\begin{abstract}
In accordance with the changes that occur in 21st century, the world's media industry also undergoes rapid changes. The variety of media that continues to emerge and develop in all levels of society has a significant impact, one of which is the board game media. This phenomenon has attracted the attention of researchers to examine board game media as a media education towards media literacy skills. Media literacy is the ability to seek, find, and use information from media messages by adapting cognitive abilities and critical thinking in analyzing and questioning media messages that are seen, read, and watched. Media literacy has a broad scope that is believed to be able to function as the stronghold for the public in ability to think critically. This study was conducted to examine the gamification mechanics element as an independent variable in the board game media literacy, focusing on the concept of media literacy based on individual competence, especially on critical understanding criteria.
\end{abstract}

Keywords: board game; critical understanding; gamification mechanics; media literacy

${ }^{1}$ Fadhilah Amalia adalah mahasiswi magister Desain

e-mail :fadhilah.amaliao7@gmail.com

2020 Institut Teknologi Bandung, Bandung dan

alumnus pada Fakultas Seni dan Desain. 


\section{Pendahuluan}

Media pembelajaran yang lazim digunakan di masa kini salah satunya adalah game edukasi. Perlu kita ketahui bahwa game memiliki beragam elemen permainan dan merupakan sebuah media temuan yang sangat menarik juga kaya akan sejarah. Sejarah permainan board game sudah dimulai sejak $3500 \mathrm{SM}$, ketika orang Mesir memainkan sebuah permainan yang disebut Senet. Board game merupakan sebuah evolusi dalam game yang menyatukan berbagai elemen permainan dengan representasi fisik dan juga bisa dipandang sebagai awal dari lahirnya simulasi gameplay. Dalam sejarahnya, permainan board game telah dikembangkan untuk tujuan pendidikan di berbagai bidang tanpa memandang batasan umur. Penelitian-penelitian terdahulu juga membuktikan bahwa dampak dari penggunaan media board game yang dirancang dengan baik sebagai media edukasi dapat memberikan sejumlah pengetahuan yang beragam (Hawkinson, 2013; Hamari, dkk, 2014; Azizan, dkk, 2018, Taspinar, dkk, 2016). Selain dari ciri-ciri elemen edukatif yang dimiliki, beragam peneliti juga telah melakukan penelitian untuk menilai karakteristik dari peserta didik menggunakan beragam skala seperti demografi, usia, jenis kelamin, hingga kemampuan literasinya. Di antara penelitian-penelitian tersebut juga terdapat peneliti yang menggunakan edukasi sebagai indikator penilaian dalam literasi media (Taspinar, dkk, 2016; Diergarten, dkk, 2017; Mihailidis, 2008; European Audiovisual Observatory, 2016).

Hingga kini penelitian terkait nilai literasi media dengan edukasi sebagai indikatornya menurut EAVI (2009) masih terbilang cukup rancu karena media edukasi belum memiliki bentuk kurikulumnya tersendiri yang secara khusus mengajarkan bentuk literasi media dalam konsep edukasi. Pendapat tersebut juga berlaku di Indonesia yang belum menerapkan edukasi literasi media secara efektif.

Seperti yang kita ketahui bahwa media itu sendiri akan terus berkembang seiring dengan berkembangnya zaman, seperti contohnya di masa lampau kita mengenal bahwa kegiatan belajar masih terbatas pada penggunaan buku fisik, dan di masa modern kini siswa dapat mengakses informasi melalui gawai/ smartphone, buku elektronik, hingga permainan yang bersifat edukatif. Melihat fenomena tersebut, muncul pertanyaan terkait bagaimana pengaruh dari literasi media sebagai sebuah karakteristik baru untuk menambah pengetahuan melalui media utamanya dalam tulisan ini adalah media edukasi board game?

Literasi tidak hanya terbatas pada kemampuan baca-tulis dari seseorang. Mengingat semakin berkembangnya ilmu pengetahuan dan teknologi di masyarakat, maka sangat wajar jika pengertian literasi juga ikut berubah seiring berkembangnya zaman. Literasi (literacy) dapat juga diartikan sebagai kemampuan seseorang dalam mencari, menemukan, dan menggunakan informasi yang diperolehnya dari beragam informasi dan pengalaman yang dimilikinya. Literasi media khususnya, dianggap sangat penting bagi khalayak dalam menambah pengetahuan tentang media.

Di dalam literasi media terdapat beberapa pendekatan yang masing-masing pendekatannya memiliki penekanan dan indikator yang berbeda sehingga metode yang digunakannya pun beragam. Salah satu pemuka literasi media tertua ialah Neil Postman (1985) yang menulis buku berjudul "Amusing Ourself to Death". Dalam bukunya, Postman menekankan pada pentingnya pendekatan pendidikan media yang bertujuan untuk melindungi 
khalayak dari potensi kecanduan media. Selain Postman, Buckingham (1990) juga merilis buku yang berjudul "Watching Media Learning" yang di dalam tulisannya, Buckingham berargumentasi tentang tingginya intensitas penggunaan media oleh anak-anak dan dikhawatirkan bahwa pengaruh yang diberikan oleh media tersebut akan sangat kuat sehingga mempengaruhi cara berpikir mereka sehingga fenomena tersebut tidak dapat diabaikan.

Dalam literatur yang luas tentang peran media dalam proses edukasi dan faktor-faktor yang mempengaruhi edukasi tersebut, penelitian tentang dampak literasi media masih terbilang baru dan belum banyak dieksplorasi. Dari penjelasan diatas, muncul pertanyaan lain terkait bagaimana kemampuan kognisi dalam literasi media di dalam media edukasi? dan bagaimana penggunaan elemen gamifikasi dalam media khususnya board game dapat menjadi pendukung motivasi belajar peserta didik ketika berhadapan dengan materi edukasi yang sarat teori?

Penelitian ini dilakukan untuk mengkaji penggunaan variabel gamifikasi mekanik sebagai indikator dampak yang ditimbulkan dari penggunaan media board game dalam kemampuan literasi media, dan membuktikan bahwa literasi media dan elemen gamifikasi dapat digunakan sebagai suatu signifikansi prediksi metode keterampilan lebih lanjut melalui media edukasi utamanya berbasis pada media board game.

\section{Metode Penelitian}

Dalam penyusunan skala tes literasi media yang telah dikonseptualisasikan oleh peneliti-peneliti terdahulu, ditemukan bahwa masing-masing tes tersebut memiliki kerangka konsep dan pengujian yang bervariatif. Bentuk pengujian- nya yang bervariatif merupakan akibat dari sifat literasi dan media itu sendiri yang terus berkembang seiring dengan berkembangnya zaman. Selain itu, literasi media juga dipengaruhi oleh proses dinamis yang melibatkan kemampuan teknis yang dimiliki (availability and context) menuju kemampuan komunikatif (communication abilities) yang dijembatani oleh kemampuan berpikir kritis seseorang (media use and critical understanding) (European Commission, 2011).

Adapun contoh tes literasi media yang pernah dilakukan oleh peneliti terdahulu diantaranya oleh Diergarten, dkk (2017) yang menguji faktor-faktor yang berpengaruh pada kemampuan belajar anak melalui film dan hypermedia menggunakan media sign literacy (MSL); European Commission (2011) yang menyusun kriteria dalam tes literasi media untuk kepentingan sosio-politik; Primack, dkk (2006) yang menyusun tes literasi media smoking media literacy (SML) untuk mengukur reliabilitas dan validitas perokok sebagai alat ukur kontrol intervensi perokok; Mihailidis (2008) yang menggunakan media literasi sebagai bahan uji kemampuan analitis siswa dalam bermedia, dan masih banyak peneliti terdahulu lainnya.

Literasi media hadir sebagai benteng bagi khalayak agar mampu bersikap kritis terhadap isi media sekaligus menentukan informasi yang dibutuhkan dari media. Ivanović (2014) dalam tulisannya juga menyebutkan bahwa edukasi media literasi merupakan elemen penting dalam edukasi kontemporer yang bisa meningkatkan kemampuan kompetensi analisa informasi. Untuk memperoleh bekal literasi media, khalayak perlu mempertimbangkan hubungan antar spesifikasi media dan memahami spesifikasi tersebut melalui faktor edukasi. 
Dalam tulisan ini, spesifikasi media board game melalui faktor edukasi yang yang memiliki potensi sebagai alat uji literasi media adalah gamifikasi mekanik. Seperti yang sudah disebutkan sebelumnya oleh Ivanović (2014) bahwa untuk memperoleh bekal literasi media khalayak perlu mempertimbangkan hubungan antar spesifikasi media, dalam hal ini spesifikasi yang memiliki potensi untuk diangkat sebagai variabel utama dalam literasi media board game adalah gamifikasi mekanik.

Desain game pada dasarnya didasarkan pada dua landasan yakni tipe pemain sebagai stereotype yang dikembangkan untuk mengkarakterisasi pemain dan mekanisme yang digunakan dalam permainan sebagai instrumen untuk menarik minat pemain. Mekanika permainan adalah aspek yang menerapkan kemampuan motivasi, kesenangan, dan sikap yang dapat menyebabkan perubahan perilaku individu, seperti mempersiapkan sesuatu/tugas atau bekerja sama dalam tim. Mekanika permainan berfungsi untuk memfasilitasi dan mendorong pemain untuk lebih bereksplorasi dan mempelajari properti ruang dan memacu mereka untuk memanfaatkan mekanisme sebagai umpan balik.

Untuk menilai tingkat literasi media remaja terhadap board game, dibutuhkan konstruksi skala literasi media yang berfokus pada media board game itu sendiri, dan yang dinilai memiliki potensi paling tinggi adalah variabel gamifikasi mekanik.

\section{Literasi Media}

Menurut Potter (2004) media literasi adalah perspektif yang muncul saat kita mengekspresikan diri dengan bermedia dan menafsirkan arti dari pesan yang kita peroleh dari media. Kita membangun perspektif kita dari struktur pengetahuan yang terbentuk dari beragam informasi dalam melakukan atau menggunakan keterampilan dalam bermedia. Dari pengertian tersebut dapat disimpulkan bahwa sebuah perspektif yang timbul dari menggunakan sebuah media dan interpretasi makna dari pesan yang kita terima dari media sebagai sebuah literasi media.

Meskipun ada banyak definisi tentang literasi media baik itu oleh organisasi internasional maupun lembaga akademis, secara umum literasi media dianggap sebagai kompetensi dalam mengatasi (secara mandiri dan kritis) keterlibatan dalam lingkungan komunikasi dan pembangunan sebuah media sebagai konsekuensi dari sebuah 'masyarakat informasi'.

Poerwaningtias, dkk (2013) menyebutkan bahwa literasi media hadir sebagai benteng bagi khalayak agar mampu bersikap kritis dalam mencari informasi-informasi yang dibutuhkan dari suatu media. Definisi literasi media biasanya mencangkup kompetensi seperti mengakses, memahami, menganalisis, mengevaluasi, membuat, berpartisipasi, dan merefleksikan pesan media. Fenomena ini memunculkan beragam bentuk tes literasi media yang telah dilakukan oleh para peneliti terdahulu (Diergarten, dkk, 2017; Mihailidis, 2008; European Audiovisual Observatory, 2016; Lopes, dkk, 2018; European Commission, 2011; Primack, dkk, 2006; Rivera-Rogel, dkk, 2017; ElGhetany, 2017).

Dalam perkembangan tes literasi media itu sendiri, Lopes, dkk (2018) menyebutkannya sebagai bentuk konstruksi tugas atau pertanyaan pada tes literasi media yang didasarkan pada model konseptual yang mencangkup dua dimensi utama yakni kognitif dan kritis (cognitive and critical), dan kreatif (creative). Dimensi kognitif dan kritis berorientasi 
untuk mengevaluasi kemampuan responden dalam mengidentifikasi dan mengenali konten media, mencari informasi, mengerti dan menafsirkan tujuan pesan, dan juga mengevaluasi informasi secara kritis. Sedangkan dimensi kreatif berorientasi pada kegiatan mengevaluasi keterampilan responden tentang pembuatan konten.

European Commission (2011) mengusulkan dua dimensi fundamental dalam literasi media, yakni: (a) Kompetensi individu (individual competences) yang didefinisikan sebagai penggunaan teknis, pemahaman kritis, dan keterampilan sosial, dan (b) Faktor Lingkungan (environmental factors) yang didefinisikan sebagai ketersediaan media, pendidikan media, kebijakan dan regulasi dan peran pemangku kepentingan lainnya dalam industri media dan masyarakat sipil. Di dalam kemampuan literasi media pada perspektif individu yang dikonsepkan oleh European Commission (2011) tersebut yakni di antaranya technical skills, critical understanding, dan social competences, disebutkan bahwa fokus utama dari literasi media adalah kemampuan 'berpikir kritis' (critical understanding). Opini tersebut juga diperkuat oleh European Audiovisual Observatory (2016) yang mengemukakan bahwa keterampilan 'berpikir kritis' merupakan keterampilan yang dianggap paling dominan dalam studi literasi media. Kemampuan kognisi dan berpikir kritis tersebut dibutuhkan untuk dapat menguraikan isi pesan yang diperoleh agar pesan menjadi lebih masuk akal atau mudah dipahami. Mihailidis (2008) juga menekankan bahwa edukasi literasi lebih berfokus pada aplikasi konten dan hasil dari pemahaman yang spesifik. Lopes, dkk (2018) juga berpendapat bahwa literasi media hadir sebagai benteng bagi khalayak agar kritis terhadap isi media dimana kemampuan kognitif dan kritis tersebut berorientasi pada kemampuan evaluasi seseorang dalam mengidentifikasi dan mengenali konten media, mencari informasi, memahami dan menafsirkan tujuan dari pesan yang diterima.

\section{Hasil dan Pembahasan}

\section{Board Game Gamifikasi Mekanik}

Board game dinilai efektif sebagai media pembelajaran karena pemain dapat secara fisik terlibat di dalam ruang dan juga berinteraksi langsung dengan elemen-elemen yang ada pada board game. Selain itu, pemain dapat secara spontan mengasumsikan diri sebagai karakter di atas board game yang mereka mainkan dan bermain peran selayaknya aktor di atas panggung. Dalam merancang sebuah board game, seringkali perancang dihadapkan dengan permasalahan dalam memilih jenis-jenis elemen permainan yang ingin digunakan. Board game khususnya dalam bidang edukasi, membutuhkan fungsi dasar belajar yang mempertimbangkan dari sisi pengajar (atau guru) yang menginginkan pelajar (atau murid) agar mampu belajar melalui metode praktik dan sosial. Board game yang dirancang tersebut tentunya diharapkan memiliki tujuan edukasi, menyesuaikan dengan apa yang ingin disampaikan atau diajarkan oleh si pengajar kepada yang diajarnya.

Hawkinson (2013) dalam tulisannya menyebutkan bahwa pengalaman bermain merupakan hasil yang muncul dari elaborasi dinamika yang berdasarkan pada pemain (player-based dynamics) dan dinamika yang berdasarkan pada permainan (game-based dynamics). Dalam merancang board game, selain dilihat dari segi pemain, perancang juga harus melihat dari segi permainan itu sendiri.

Seringkali perancang sulit membeda- 
kan antara tema dengan cerita yang ingin dibawakan. Tema (theme) pada media board game edukasi merupakan fungsi dasar pembelajaran yang ingin disampaikan kepada kepada pelajar (atau murid) oleh pengajarnya (atau guru), sedangkan cerita (story) adalah background yang melatari suatu board game. Tema dalam permainan lebih mendekati definisi prinsip atau konsep yang ada pada permainan itu sendiri, contohnya dalam merancang board game matematika tentang menghitung penjumlahan,pengurangan, perkalian, dan pembagian, maka tema yang digunakan adalah hitungan- hitungan kombinasi angka yang menggunakan rumus penjumlahan, pengurangan, perkalian, dan pembagian. Dari tema tersebut bisa ditarik kesimpulan bahwa mekanika (mechanics) permainan yang harus digunakan adalah berhitung.

Game mechanics adalah elemen paling rumit yang ada dalam permainan board game dikarenakan karakteristik game mechanics yang meliputi fungsi-fungsi board game yang melibatkan interaktivitas dalam suatu permainan. Dalam board game itu sendiri, mechanics sering kali dianggap sebagai sekumpulan peraturan yang harus ditaati, namun juga meliputi detil yang dibangun di dalam permainan secara objek fisik (contoh: serangkaian bidak dan papan permainan). Tanpa adanya susunan mekanik, board game tersebut hanya akan berakhir sebagai permainan bebas tanpa aturan. Contoh mekanika permainan bisa meliputi hal-hal seperti sistematisasi pembagian giliran antar pemain hingga bentuk elaborasi sebab-akibat dalam suatu permainan.

Mekanika permainan (game mechanics) memiliki beragam bentuk yang dapat digunakan oleh perancang dalam mendesain sebuah media board game. Dalam mendesain board game edukasi, perancang dapat memulai dari membuat me- kanika permainan berdasarkan konsep gamifikasi yang ingin dibuat.

Gamifikasi itu sendiri dalam konteks perancangan media board game edukasi merupakan penggunaan unsur-unsur mekanik yang ada pada board game untuk menyampaikan tujuan pembelajaran dengan cara membangun sebuah ketertarikan (engagement). Menurut Kapp (2012), gamifikasi atau game-based-techniques menggunakan kombinasi konsep game-based mechanics, konsep keindahan dan proses berpikir bermain untuk menarik minat individu, konsep aksi yang memotivasi, mempromosikan konsep pembelajaran, dan konsep memecahkan permasalahan. Hamari, dkk (2014) dalam literature review-nya juga menyebutkan bahwa semua penelitian terkait konteks edukasi sebagai hasil dari proses gamifikasi memberikan dampak yang sebagian besar positif, salah satunya dalam meningkatkan motivasi belajar yang melibatkan rasa senang, namun disebutkan juga bahwa terdapat dampak yang cenderung negatif yang membutuhkan perhatian khusus, contohnya: meningkatnya rasa kompetitif yang berlebihan.

Dalam perkembangannya, gamifikasi memiliki beragam taksonomi yang telah dikemukakan oleh banyak peneliti terdahulu. Melihat banyaknya ragam taksonomi yang ada tersebut, penulis akan menggunakan taksonomi gamifikasi yang dikemukakan oleh Marczewski (2015) sebagai representasi utama dalam mengkaji variabel gamifikasi mekanik sebagai variabel dalam literasi media board game pada tulisan ini.

Marczewski (2015) dalam tulisannya membahas fase yang dianggap penting untuk mempertahankan pemain agar cukup termotivasi dalam sistem permainan dan pada prosesnya ia mengembangkan konsep yang dapat digunakan 
sebagai dasar diskusi mengenai tipe pemain. Dari konsep yang dikembangkan tersebut, kita dapat melihat secara khusus tipe-tipe pemain yang ada dan bagaimana cara mengeksploitasi faktor-faktor khusus yang mempengaruhi motivasi dari masing-masing tipe pemain tersebut.

Mengutip pada tulisan Bartle (2014) yang telah merumuskan taksonomi tipe pemain sebelumnya sebagai basis dalam perancangan game MUD (Multi-User Dungeon), ia membagi tipe tersebut ke dalam empat bagian yakni: achievers, explorers, socializers, dan killers:

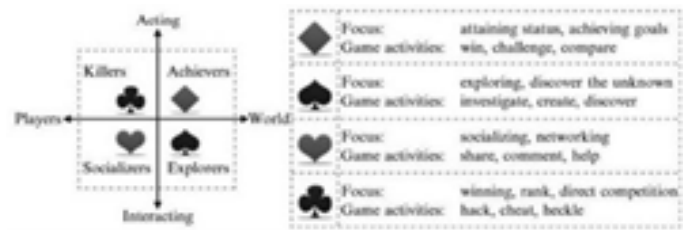

Gambar 1. Bartle taxonomy of player types

Menggunakan taksonomi Bartle (2014) tersebut sebagai referensi, Marczewski (2015) mengembangkan 5 tipe pemain baru yang ia sebutkan sebagai tipe pemain HEXAD meliputi: (1) Socializer, yakni tipe yang dimotivasi oleh hubungan sosial; (2) Free Spirits, yakni tipe yang dimotivasi oleh otonomi dan ekspresi diri (autonomy) dengan berkreasi dan bereksplorasi; (3) Achievers, yakni tpe yang dimotivasi oleh kegiatan penguasaan (mastery) untuk meningkatkan potensi diri; (4) Philanthropists, yakni tipe yang dimotivasi oleh makna dan tujuan permainan dan cenderung altruistik; (4) Players, yakni tipe yang dimotivasi oleh hadiah (rewards); dan (5) Disruptors, yakni tipe yang dimotivasi oleh faktor perubahan dengan cara mengusik sistem yang sudah ada, terlepas dari apakah hasilnya akan mengarah pada perubahan yang bersifat positif atau negatif.

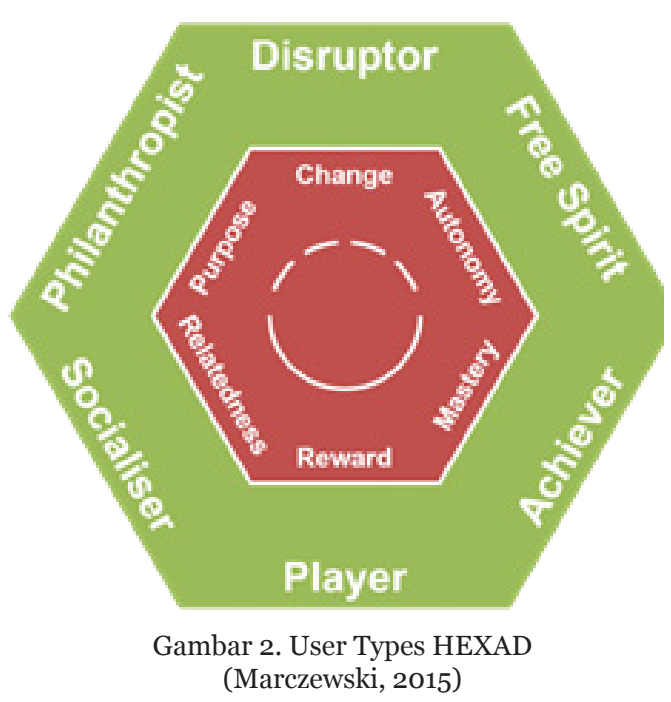

Lebih lanjut, Marczewski (2015) juga mengusulkan 52 jenis elemen dan mekanik yang mendukung masing-masing jenis tipe pemain HEXAD (Gambar 2) dan ragam konteks yang dapat meningkatkan pengalaman bermain ke dalam sebuah tabel periodik:

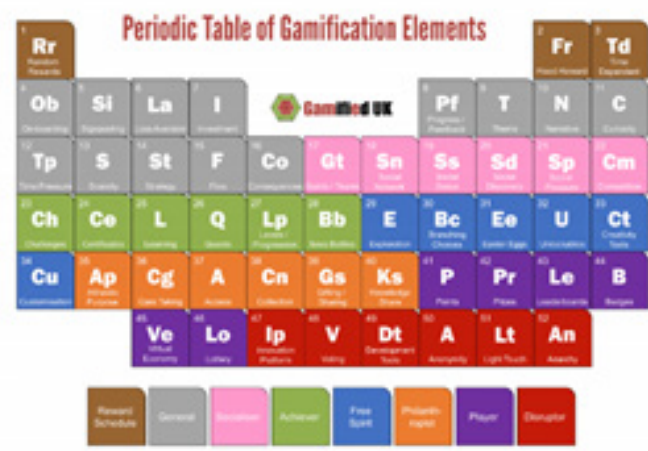

Gambar 3. The Periodic Table of Gamification Elements oleh Andrezej Marczewski (sumber: gamified.uk)

\section{Hubungan Elemen Gamifikasi Me- kanik dengan Model Literasi Media}

Sebelum membahas tentang hubungkan relasi antara elemen gamifikasi mekanik dengan literasi media, perlu kita bahas terlebih dahulu tentang model lit- 
erasi media itu sendiri. Kellner \& Share (2007) terinspirasi dari model pendekatan Postman (1985) menyebutkan terdapat setidaknya empat pendekatan literasi media yakni: (1) Pendekatan kuasa media (The powerful media) yang menyebutkan bahwa media memiliki kuasa atas penggunanya; (2) Pendekatan pendidikan seni media (Media arts education), yakni pembelajaran konstruksi pesan media dengan penekanan pada perspektif literasi medianya meliputi kemampuan teknis dan kesadaran implikasi ideologi atau sosial kritis; (3) Pendekatan gerakan literasi (Literacy Movement), yakni upaya perluasan pengertian literasi media yang tidak terbatas pada kemampuan baca-tulis namun mencangkup budaya populer seperti musik, video, internet, iklan, dan lain sebagainya; dan (4) Pendekatan literasi media kritis (Critical Media Literacy) yang merupakan bentuk kombinasi dari ketiga pendekatan yang telah disebutkan sebelumnya dengan menekankan pada kritik ideologi dan politik dalam beragam dimensi seperti usia, gender, ras, dan sebagainya.

Adapun esensi yang ada dalam kompetensi digital dan media literasi yang dijelaskan oleh Hobbs (2010) di antaranya terdapat lima fundamental dalam keterampilan belajar dalam berbagai subjek, yakni: (1) mengakses (access) atau kemampuan dalam menemukan dan menggunakan media secara fasih; (2) menganalisis (analyze) pesan yang diperoleh menggunakan proses berpikir kritis; (3) membuat (create) atau menciptakan konten media secara kreatif; (4) merefleksi (reflect) atau kemampuan dalam mengaplikasikan tanggung jawab sosial dan prinsip etnik yang ada; dan (5) peran (act) yakni bekerja secara individual maupun kolaboratif dalam berbagi pengetahuan dan memecahkan suatu permasalahan.

Dari penjelasan model literasi media di atas, secara umum dapat disimpulkan bahwa media literasi dapat dievaluasi berdasarkan: (1) bagaimana individu dapat memahami konsep utama dari literasi media dan konsep spesifik atau ide yang diperoleh dari hasil eksplorasi saat berinteraksi dengan media; (2) bagaimana kedalaman dan kualitas individu dalam mempertanyakan dan menganalisis pertanyaan yang muncul dari interaksi media dan juga proses berpikir individu dalam mengidentifikasi isu-isu yang ada; dan (3) bagaimana kemampuan individu dalam mengaplikasikan kemampuan teknis mereka saat berasosiasi dengan medium yang dipelajari (Televisi, game, buku, film, dan lain sebagainya).

Dalam memetakan kemampuan literasi media utamanya pada fokus perspektif individu, penulis akan menggunakan metode penilaian literasi media yang mereferensi pada jurnal Testing and Refining Criteria to Assess Media Literacy in Europe Final Report (European Commission, 2011). Dalam jurnal tersebut disebutkan bahwa terdapat tiga kriteria variabel yang menggambarkan kemampuan kompetensi individu (individual competences) yakni: technical skills, critical understanding, dan social competences.

Dalam piramida (Gambar 4) yang

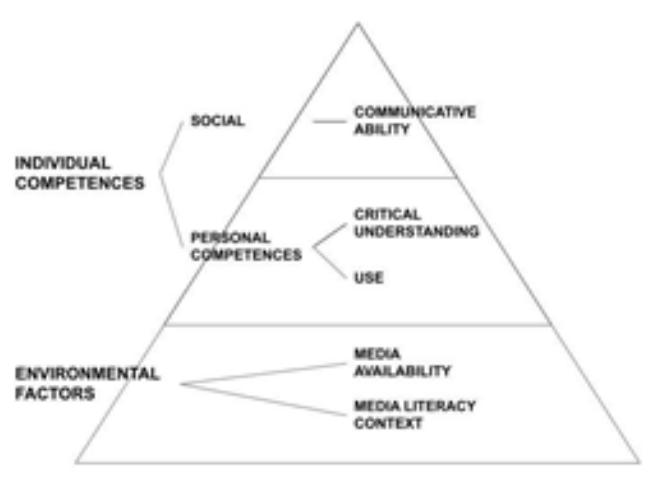

Gambar 4. Struktur kriteria penilaian literasi media (sumber: European Commission, 2011) 
dikonseptualisasikan oleh European Commission (2011) di atas, dapat kita lihat bahwa kemampuan komunikasi berada pada puncak piramida. Kemampuan komunikasi/ sosial dapat dikatakan sebagai hasil manifestasi dari kemampuan literasi media. Kemampuan itu muncul secara natural dalam kegiatan partisipatif sosial dalam bermedia dan aktivitas membuat konten media itu sendiri. Meski European Commission memposisikan kemampuan komunikasi sebagai bagian dari aspek media literasi, aspek tersebut oleh mereka masih dianggap rancu karena menurut mereka, keterampilan hubungan sosial dan partisipatif sosial membutuhkan pemahaman berpikir kritis (critical understanding) yang akhirnya memunculkan argumentasi bahwa tingkat partisipatif sosial menjadi puncak dalam tingkat/ level literasi media tinggi (high media literacy levels).

Terlepas dari kemampuan komunikasi, kemampuan berpikir kritis (critical understanding) lebih dianggap sebagai bagian dan fokus utama dalam perkembangan kompetensi literasi media yang di dalamnya mencangkup aspek dalam hubungan relasi antar individu dengan media, termasuk di dalamnya kemampuan kognitif dan nilai kapasitas individu terkait dengan pengetahuan operasi semiotik: encoding/ decoding, menafsirkan, dan mengevaluasi teks media.

Selain kemampuan kompetensi individu (individual competencies), terdapat faktor lain yang bisa kita lihat pada piramida yang dikemukakan oleh European Commission di atas yakni faktor lingkungan (environmental factor). Di dalam masyarakat, struktur eksternal seperti ketersediaan media, edukasi literasi media, dan kebijakan masyarakat dan industri lebih dianggap sebagai keadaan yang kondusif bagi kemajuan literasi media dalam skala masyarakat. Oleh karenan- ya European Commission (2011) memisahkan kompetensi individu (individual competencies) dengan faktor lingkungan (environmental factors) ke dalam dua dimensi yang berbeda.

Melihat karakteristik literasi media yang disebutkan oleh Kellner \& Share (2007), Hobbs (2010), dan European Commission (2011) tersebut maka tidaklah aneh apabila gamifikasi mekanik dianggap memiliki potensi besar sebagai variabel skala literasi media untuk media board game.

Dalam studi yang dilakukan oleh Gil, dkk (2015), ditemukan bahwa terdapat relevansi dalam validasi mekanika gamifikasi dengan tipe pemain dalam edukasi, yakni pada kemampuan siswa dalam bertindak di kegiatan pembelajaran memiliki hubungan dengan tipe-tipe pemain tertentu. Lebih jauh, Gil, dkk juga menyebutkan bahwa identifikasi mekanisme gamifikasi tertentu yang dianggap lebih relevan dalam penggunaannya sebagai mekanika berbasis kolaboratif dan tantangan (collaborative and challenge-based mechanics).

Banyak literatur terdahulu yang telah menyebutkan bahwa board game memiliki kemampuan untuk meningkatkan level motivasi belajar individu, contohnya pada perancangan board game yang dirancang untuk tujuan mengedukasi kemampuan bahasa khusus (Hawkinson, 2013), penggunaan board game dalam manajemen pengetahuan (Taspinar, dkk, 2016), dan lain sebagainya. Dalam merancang board game, jenis elemen yang akan digunakan dalam proses bermain tentunya berpengaruh pada kemampuan motivasi belajar individu, faktanya berbeda jenis pelajar tentunya membutuhkan stimulasi dan pendekatan yang berbeda untuk dapat meningkatkan motivasi belajar mereka.

Untuk menilai dampak dari litera- 
si media terhadap media edukasi board game, diperlukan struktur penilaian dalam bentuk survey yang mencangkup di dalamnya konsep penilaian tingkatan literasi media melalui sikap responden terhadap media board game, utamanya dalam tulisan ini adalah variabel elemen gamifikasi mekanik sebagai salah satu indikatornya.

Mengingat kompleksitas dalam konsep literasi media, penulis akan berfokus pada dimensi kompetensi dalam perspektif individu untuk mengkaji hubungan gamifikasi mekanik dengan literasi media board game. Kompetensi individu berfokus pada kemampuan mengakses, menggunakan, memahami, dan menciptakan konten. Dimensi ini memiliki cangkupan yang lebih luas dan memungkinkan adanya peningkatan tingkat kesadaran, kapasitas berpikir kritis, kapasitas dalam melakukan problem solving, dan kemampuan berkomunikasi melalui konten media dalam kehidupan publik. Faktor-faktor yang mempengaruhi individu dalam berkegiatan dengan edukasi media, kebijakan media, dan perannya dalam industri media akan dijabarkan lebih lanjut dalam bentuk kriteria/ indikator.

Sebelumnya telah disebutkan bahwa kemampuan berpikir kritis (critical understanding) merupakan keterampilan yang dianggap paling dominan dalam studi literasi media. Di dalamnya terdapat tiga komponen penting yang juga dikemukakan oleh European Commission (2011) yakni: (1) memahami konten media dan fungsinya; (2) pengetahuan tentang media dan media regulasi; dan (3) perilaku pengguna.

Dari hasil kajian yang telah dijabarkan sebelumnya, ditemukan bahwa penggunaan gamifikasi mekanik dalam literasi media memiliki kaitan erat dengan komponen memahami konten me- dia dan fungsinya. Komponen tersebut dapat diuraikan ke dalam 3 faktor yakni: (1) persepsi pengguna (Reliability Perception); (2) kesadaran akan pembedaan (Awareness of Differences); (3) kesadaran akan potensi efek media (Awareness of Potential Media Effects); dan (4) tingkat literasi fungsional (Higher Functional Literacy).

Tabel 1. Interpretasi dimensi hubungan faktor literasi media dengan gamifikasi mekanik

\begin{tabular}{|c|c|}
\hline Faktor & Dimensi \\
\hline $\begin{array}{l}\text { Persepsi } \\
\text { Kegunaan } \\
\text { (Reliability } \\
\text { Perception) }\end{array}$ & $\begin{array}{l}\text { Penilaian } \\
\text { kegunaan media } \\
\text { board game } \\
\text { sebagai media } \\
\text { penyampaian } \\
\text { informasi. }\end{array}$ \\
\hline $\begin{array}{l}\text { Kesadaran akan } \\
\text { Pembedaan } \\
\text { (Awareness of } \\
\text { Differences) }\end{array}$ & $\begin{array}{l}\text { Penilaian } \\
\text { individual terkait } \\
\text { opini individu } \\
\text { terhadap } \\
\text { perwujudan } \\
\text { perbedaan dalam } \\
\text { penerimaan } \\
\text { informasi yang } \\
\text { sama dari } \\
\text { penggambaran } \\
\text { elemen gamifikasi } \\
\text { mekanik yang } \\
\text { berbeda. }\end{array}$ \\
\hline $\begin{array}{l}\text { Kesadaran akan } \\
\text { Potensi Efek } \\
\text { Media } \\
\text { (Awareness of } \\
\text { Potential Media } \\
\text { Effects) }\end{array}$ & $\begin{array}{l}\text { Kesadaran potensi } \\
\text { media board game } \\
\text { menggunakan } \\
\text { elemen-elemen } \\
\text { gamifikasi } \\
\text { mekanik sebagai } \\
\text { basis. }\end{array}$ \\
\hline $\begin{array}{l}\text { Tingkat Literasi } \\
\text { Fungsional } \\
\text { (Higher } \\
\text { Functional } \\
\text { Literacy) }\end{array}$ & $\begin{array}{l}\text { Penilaian individu } \\
\text { berdasarkan pada } \\
\text { kemampuan } \\
\text { literasi mereka } \\
\text { berkaitan dengan } \\
\text { konteks informasi } \\
\text { media board } \\
\text { game. }\end{array}$ \\
\hline
\end{tabular}


Fadhilah Amalia ${ }^{1}$

Alvanov Zpalanzani Mansoor ${ }^{2}$
Kajian Gamifikasi Mekanik sebagai Variabel dalam Literasi Media Board

Game
Hasil interpretasi dimensi dari hasil menghubungkan ketiga faktor tersebut dengan elemen gamifikasi mekanik board game dapat dilihat pada tabel 1 .

Dari interpretasi di atas dapat dilihat bahwa gamifikasi mekanik memiliki potensi sebagai variabel dalam penulisan skala literasi media board game. Sebagai contoh, penulis akan menuliskan skala pengukuran literasi media keterampilan belajar siswa dalam bertindak di kegiatan pembelajaran menggunakan media board game dan kesesuaiannya terhadap tipe pemain, menggunakan taksonomi gamifikasi mekanik Marczewski (2015) yang kemudian akan dikaitkan dengan model literasi media dimensi kompetensi individu (individual competencies) untuk menilai faktor kesadarakan akan potensi efek media (Awareness of Potential Media Effects), sebagai berikut:

Tabel 2. Contoh asumsi tindakan individu, gamifikasi mekanik, dan tipe pemain

\begin{tabular}{|l|l|l|}
\hline \multicolumn{1}{|c|}{ Tindakan } & Mekanik & $\begin{array}{c}\text { Tipe } \\
\text { Pemain }\end{array}$ \\
\hline $\begin{array}{l}\text { Memilih untuk } \\
\text { memecahkan } \\
\text { tantangan } \\
\text { sendiri }\end{array}$ & Challenge & Achiever \\
\cline { 1 - 2 } $\begin{array}{l}\text { Menerima } \\
\text { medal karena } \\
\text { menyelesaikan } \\
\text { tantangan } \\
\text { dalam kuota } \\
\text { tertentu }\end{array}$ & Quest & \\
\cline { 1 - 2 } $\begin{array}{l}\text { Memilih untuk } \\
\text { bekerja dalam } \\
\text { tim }\end{array}$ & $\begin{array}{l}\text { Team/ } \\
\text { Guilds }\end{array}$ & $\begin{array}{l}\text { Socialiser } \\
\text { ser }\end{array}$ \\
\cline { 1 - 2 } $\begin{array}{l}\text { Membuat } \\
\text { relasi dengan } \\
\text { individu lain } \\
\text { yang } \\
\text { membuatnya } \\
\text { merasa } \\
\text { nyaman untuk } \\
\text { bekerja sama }\end{array}$ & $\begin{array}{l}\text { Social } \\
\text { networkin } \\
g\end{array}$ & \\
\hline
\end{tabular}

\begin{tabular}{|c|c|c|}
\hline $\begin{array}{l}\text { Menerima } \\
\text { medal dari } \\
\text { orang yang } \\
\text { merasa } \\
\text { terbantu saat } \\
\text { menyelesaikan } \\
\text { tantangan }\end{array}$ & $\begin{array}{l}\text { Meaning/ } \\
\text { Purpose }\end{array}$ & \multirow[t]{2}{*}{$\begin{array}{l}\text { Philanthr } \\
\text { opist }\end{array}$} \\
\hline $\begin{array}{l}\text { Menanyakan } \\
\text { guru/ sistem } \\
\text { atas solusi dari } \\
\text { tantangan }\end{array}$ & Access & \\
\hline $\begin{array}{l}\text { Memilih untuk } \\
\text { memecahkan } \\
\text { tantangan } \\
\text { sendiri }\end{array}$ & $\begin{array}{l}\text { Exploratio } \\
n\end{array}$ & \multirow[t]{2}{*}{$\begin{array}{l}\text { Free } \\
\text { Spirits }\end{array}$} \\
\hline $\begin{array}{l}\text { Menerima } \\
\text { medal karena } \\
\text { menanyakan } \\
\text { guru/ sistem } \\
\text { dan } \\
\text { memecahkan } \\
\text { tantangan di } \\
\text { luar topik } \\
\text { pembelajaran }\end{array}$ & $\begin{array}{l}\text { Unlockable } \\
\text { /Rare } \\
\text { Content }\end{array}$ & \\
\hline $\begin{array}{l}\text { Memilih untuk } \\
\text { berpikir di luar } \\
\text { nalar (out of } \\
\text { the box) dari } \\
\text { sistem } \\
\text { permainan } \\
\text { yang telah } \\
\text { disediakan }\end{array}$ & $\begin{array}{l}\text { Innovation } \\
\text { Platform }\end{array}$ & \multirow[t]{2}{*}{ Disruptor } \\
\hline $\begin{array}{l}\text { Memilih untuk } \\
\text { mengabaikan } \\
\text { aturan yang } \\
\text { sudah ada dan } \\
\text { mulai bermain } \\
\text { dengan aturan } \\
\text { baru }\end{array}$ & Anarchy & \\
\hline & dsb & \\
\hline
\end{tabular}

\section{Kesimpulan}

Dari kajian ini, dapat disimpulkan bahwa media board game yang dirancang untuk tujuan edukasi memiliki bentuk yang sangat kompleks dan membutuhkan pertimbangan kritis dalam penggu- 
naan ragam gamifikasi mekanik. Di luar dari dampaknya yang mayoritas positif, ditemukan juga bahwa board game edukasi itu sendiri memiliki potensi memunculkan kontroversi yang bisa jadi berpotensi pada hasil yang cenderung negatif.

Melihat fenomena tersebut, perkembangan literasi media board game khususnya pada kemampuan berpikir kritis (critical understanding) menjadi fokus utama pada kompetensi individu yang di dalamnya mencangkup aspek dalam hubungan relasi antar individu dengan media. Untuk memahami dan menguraikan pesan media, individu perlu menguraikan isi pesan tersebut agar menjadi lebih masuk akal dan mudah dipahami sekaligus mampu menggunakan manfaat yang disajikan sambil menghindari potensi dari dampak negatifnya. Kegiatan tersebut sangat membutuhkan kemampuan kognisi dan adaptasi pengetahuan dasar individu terkait dengan pesan yang ingin diuraikan dari media terkait.

Dengan mengakui adanya efek dari penggunaan gamifikasi mekanik dari segi perilaku melalui penerapan literasi media board game, diharapkan akan mengajarkan cara untuk memahami, menganalisis, mengevaluasi, dan memanfaatkan pesan agar individu dapat secara aktif dan mampu berpikir lebih kritis dalam memproses pesan media yang diperoleh dari media edukasi board game daripada hanya menjadi target media secara pasif dan menerima informasi secara mentah.

\section{Referensi}

Azizan, M. T., Mellon, N., Ramli, R. M., \& Yusup, S. (2018). Improving teamwork skills and enhancing deep learning via development of board game using cooperative learning method in Reaction Engineering course. Ed- ucation for Chemical Engineers, 22, 1-13. https://doi.org/10.1016/j. ece.2017.10.002

Bartle, R. (2014). HEARTS , CLUBS , DIAMONDS , SPADES : August.

Buckingham, D. (1990). Watching Media Learning.

Diergarten, A. K., Möckel, T., Nieding, G., \& Ohler, P. (2017). The impact of media literacy on children's learning from films and hypermedia. Journal of Applied Developmental Psychology, 48, 33-41. https://doi.org/10.1016/j. appdev.2016.11.007

EAVI. (2009). Study on Assessment Criteria for Media Literacy Levels: A comprehensive view of the concept of media literacy and an understanding of how media literacy levels in Europe should be assessed. European Association for Viewers' Interests, October, 1-92.

ElGhetany, S. S. (2017). The Challenges and the Policies of Media Literacy Programs in Egyptian Schools. http://dar.aucegypt.edu/bitstream/ handle/10526/5055/Salma El Ghetany-Thesis-Media Literacy-Final-Spring 2017.pdf? sequence $=3$

European Audiovisual Observatory. (2016). Mapping of media literacy practices and actions in EU-28. https://doi.org/10.2759/111731

European Commission. (2011). Testing and Refining Criteria to Assess Media Literacy Levels in Europe Final Report. April, 1-217. http://www.eavi. eu/joomla/images/stories/Publications/study_testing_and_refining_ ml_levels_in_europe.pdf

Gil, B., Cantador, I., \& Marczewski, A. (2015). Validating Gamification Mechanics and Player Types in an E-learning Environment. EC-TEL 
2015, 9307(January). https://doi. org/10.1007/978-3-319-24258-3_61

Hamari, J., Koivisto, J., \& Sarsa, H. (2014). Does gamification work? - A literature review of empirical studies on gamification. Proceedings of the Annual Hawaii International Conference on System Sciences, 3025-3034. https:// doi.org/10.1109/HICSS.2014.377

Hawkinson, E. (2013). Board Game Design and Implementation for Specific Learning Goals. In The Asian Conference on Language Learning 2013 Official Conference Proceedings 2013, 317-326.

Hobbs, R. (2010). Digital_and_Media_ Literacy_A_Plan_of_Action.pdf.

Ivanović, M. (2014). Development of Media Literacy - An Important Aspect of Modern Education. Procedia - Social and Behavioral Sciences, 149, 438-442. https://doi.org/10.1016/j. sbspro.2014.08.284

Kapp, K. M. (2012). The Gamification of Learning and Instruction. Pfeiffer.

Kellner, D., \& Share, J. (2007). Critical media literacy is not an option. Learning Inquiry, 1(1), 59-69. https://doi. org/10.1007/s11519-007-0004-2

Lopes, P., Costa, P., Araujo, L., \& Ávila, P. (2018). Measuring media and information literacy skills: Construction of a test. Communications, 43(4), 508534. https://doi.org/10.1515/commun-2017-0051

Marczewski, A. (2015). Even Ninja Monkeys Like to Play: Gamification, Game Thinking and Motivational Design. Gamified UK.

Mihailidis, P. (2008). Beyond Cynicism: How Media Literacy Can Make Students More Engaged Citizens. April 2008. http://drum.lib.umd.edu/bitstream/1903/8301/1/umi-umd-5277. pdf

Poerwaningtias, Intania; Rianto, Puji; Ni'am, Maulin; Adiputra, Wisnu A.; Marganingtyas, Djati; Mirasari, Endang; Misbah, N. A. (2013). Model Gerakan Literasi Media \& Pemantauan Media (P. Rianto (ed.)). Pusat Kajian Media dan Budaya Populer \& Yayasan TIFA.

Postman, N. (1985). Amusing Ourself to Death. Penguin Books.

Potter, W. J. (2004). Theory of Media Literacy: A Cognitive Approach. Sage Publications.

Primack, B. A., Gold, M. A., Switzer, G. E., Hobbs, R., Land, S. R., \& Fine, M. J. (2006). Development and validation of a smoking media literacy scale for adolescents. Archives of Pediatrics and Adolescent Medicine, 160(4), 369-374. https://doi.org/10.1001/ archpedi.160.4.369

Rivera-Rogel, D., Zuluaga-Arias, L. I., Ramírez, N. M. M., Romero-Rodríguez, L. M., \& Aguaded, I. (2017). Media competencies for the citizenship training of teachers from Andean America: Colombia and Ecuador. Paideia, 27(66), 80-89. https://doi. org/10.1590/1982-43272766201710

Taspinar, B., Schmidt, W., \& Schuhbauer, H. (2016a). Gamification in education: A board game approach to knowledge acquisition. Procedia Computer Science, 99, 101-116. https://doi. org/10.1016/j.procs.2016.09.104

Taspinar, B., Schmidt, W., \& Schuhbauer, H. (2016b). Gamification in education: A board game approach to knowledge acquisition. Procedia Computer Science, 99(October), 101-116. https:// doi.org/10.1016/j.procs.2016.09.104 